\title{
Political Corruption in Africa: The Decisive Role of the African State
}

\author{
Benjamin Akwei, PhD* \\ Adjunct Assistant Professor International Relations \& Comparative Politics \& Government (Africa \& Middle East) \\ University of Bridgeport College of Public \& International Affairs 303 University Avenue Bridgeport, CT. O6604. USA
}

*Corresponding Author

Benjamin Akwei, PhD

\section{Article History}

Received: 03.02.2020

Accepted: 11.02 .2020

Published: 18.04.2020

\begin{abstract}
The principal-agent and institutional corruption models which in the past three decades have become the predominant and mainstream theoretical explanations to the demand and supply sides of corruption have failed to adequately examine the role of the nature and character of the African state in addressing political corruption in Africa's authoritative regimes and democracies. Are Africa's democratic regimes less corrupt than the authoritarian ones they succeeded? In this paper, I provide a historical analysis of how literatures associating political corruption with regime types in Africa have been inadequate in addressing the issue. Alternative explanatory models addressing political corruption must be explored in Africa, where the ruling political elites, a strong force in society use the state as an arena to extract resources away from their societies to benefit both domestic and foreign solidarities, as the heroic assumption that African leaders, such as autocrats, high-levels officials or elected politicians, are genuinely interested in curbing corruption have been a façade.
\end{abstract}

Keywords: Decisive Role, Political Corruption, predominant.

\section{Theorizing on political corruption}

Corruption has been the subject of a substantial amount of theorizing and empirical research over the last 50 years, and this has produced a bewildering array of alternative explanations, and typologies [1]. The principal-agent and institutional models of corruption which predominantly have been dominant in economics and political science, models corruption on the criminal behaviors of some agents who acts on behalf of some principals [2, 3] and designing institutions, such as electoral systems or forms of government, so as to strengthen accountability and minimize the incidence of rent-seeking and/or corruption [4-6] respectively to uprooting corruption. The principal-agent and institutional models of corruption emphasize a vertical dimension of conflict between rulers and ruled or electors and elected, and a horizontal conflict between different sectors of society which may benefit or lose from corruption respectively have provided explanations to the demand and supply sides of corruption [7]. These models of corruption which emphasize conflicts and benefits between state-society relationships to corruption, fail to define political corruption by examining the critical role played by the character and nature of the state as an instrumental actor in development and serving as an arena for the extraction of public resources for both domestic and foreign solidarities especially in Third World countries. The issue of corruption has to some extent entered the political and economic sciences from the interests of the role of the state in the developing world, and in particular from the idea that the state is an indispensable instrument for economic development. The 1997 World Development Report stated that "an effective state is vital for the provision of the goods and services-and the rules and institutions- that allow markets to flourish and people to lead healthier, happier lives. Without it, sustainable development, both economic and social is impossible [8]. Because of the upsurge of interests in the state especially in economic development, and the involvement of state officials in corruption, the state, has become the most important actor on theorizing and in the definitions of corruption. The decisive role of the state is also reflected in most definitions of corruption. On the one side is the state, that is the civil servants, functionaries, bureaucrats and politicians, anyone who holds a position of authority to allocate rights over (scarce) public resources in the name of the state or the government [1]. When a political scientist finds that many government actions are heavily influenced by a pattern of bribery or by obligations to close kin and friends, he is likely to ask how the situation affects the distribution of power and authority in the political system, how it distorts the formal

Copyright @ 2020: This is an open-access article distributed under the terms of the Creative Commons Attribution license which permits unrestricted use, distribution, and reproduction in any medium for non commercial use (NonCommercial, or CC-BY-NC) provided the original author and source are credited. 
declarations of government policy, how it influences the character and composition of the political elite over time [9]. The role played by political decision-makers who use the political power that they are armed with to sustain their power, status and wealth, associates political corruption with the state. The Beckerian association of corruption with the state is the result of a conflation of two different phenomena, namely the existence of the state and the control of power within the state. It is not the existence of the state per se that generates corruption but it is the concentration of power within the state that makes corruption possible. Lord's Actor's dictum has it that (all power tends to corrupt and absolute power corrupts absolutely" [10]. The role played by political decision-makers who use the state as an instrument to sustain their political power, status and wealth contributed to theorizing on political corruption. Political corruption, though not a recent phenomenon has gained international traction for the past six decades with researchers from all disciplines theorising and offering alternative explanations on how to curtail its effects on society. Every political system has been corrupt at some point in history. The upsurge of academic interest in political corruption in the 1960s produced a spate of new definitions. For the most part, these definitions were new in the sense used by purveyors of detergents. They consisted largely in elaborations or re-formulations of the legal/public office meaning which was thought to be more compatible with the goal of the value-free social science. Thus, the legal/office meaning was stretched and strained as analysts sought to formulate a definition which was simultaneously general enough to permit comparative study and yet specific enough to justify making valid observations on countries. The early appreciation that laws vary from country to country discouraged a purely legal emphasis and ensured that increasing reference was made to public office definitions [11]. If the study of corruption teaches us anything at all, it teaches us not to take a political system or a regime at its face value. Corruption after all, may be an informal political system. Whereas party manifestos, general legislations, and policy declarations are the formal façade of the political structure, corruption stands in sharp contrast to the se features as an informal political system. For most nations at some point in their history, and for many nations today, however, the surreptitious politics of this arena is so decisive that an analysis which ignored it would be not simply inaccurate but completely misleading [9]. In the 1700s, Britain was viewed by American colonists as very corrupt [12]. As an informal political system, often have similar causes, patterns, and consequences in different political contexts. We can discern similar forces at work, for instance, in the bribe a Chinese peasant might have paid a mandarin bureaucrat to escape the annual head tax a century ago and in the money a Ghanaian farmer gives a tax official to underpasses his annual income [9]. Corruption exists in all bureaucracies and political systems around the world. It is not a developing country problem; it is not an African problem. However, corruption causes more damage to the African people than to developed countries' populations [13]. In recent years the fight against corruption has become a major industry, involving all the major international organizations [14-16]. Causal analyses of corruption typically fall into one of three broad categories. The first focuses on societal and historical factors, such as: economic development and the structure of the economy; population density; and geography, mineral wealth and unearned taxes; the timing and process of state formation; colonial legacies; societal heterogeneity, clientalism, cronyism, patrimonialism, and social inequality; religion, gender, social trust and social capital; a strong, independent and well attended media and political culture. Another genre studies the role of public policies, including tax structure, trade policy, revenue expenditures and regulatory burdens. A third line of analysis highlights the role of international actors and organizations and management of the public sector [17]. These three causal analyses of corruption make defining political corruption a highly ambiguous and contested concept. A clear definition of political corruption which has come to dominate political and economic theories in the past three decades is very problematic but there are indicative ways in which political corruption can be distinguished from other forms of political failure, such as incompetence. The ease with which we move from clear cut to ambiguous cases underlines the importance of reaching a clear definition of political corruption, even as it suggests the difficulties associated in so doing. Despite the substantial problems raised in the definition of political corruption, there are cases which seem incontestably corrupt. We can recognize political corruption where:

\section{A public official (A)}

2. In violation of the trust placed in him by the public (B),

3. And in a manner which harms the public interest,

4. Knowingly engages in conduct which exploits the office for clear personal and private gain in a way which runs contrary to the accepted rules and standards for the conduct of public office, within the political culture,

5. So as to benefit a third party (C) by providing $C$ with access to a good or service $C$ would not other obtains [18].

These distinctive ways shared and identified by most political scientists can be distinguished from other forms of political failures, which lay the grounds for a shared definition of political corruption. Political corruption is any transaction between private and public-sector actors through which collective goods are illegitimately converted into private-regarding payoffs $[10,1]$. In a stricter definition, political corruption involves political decision-makers. Political or grand corruption takes place at the high levels of the political system. It is when the politicians and state agents, who are entitled to make and enforce the laws in the name of the people, are themselves corrupt. Political corruption is the political institutions and the rules of procedures, and therefore it influences the institutions of government and the political system, and it frequently leads to institutional decay. Political corruption is therefore something more than a deviation from normal and written legal norms, from professional codes of ethics and court rulings. Political corruption is 
when laws and regulations are systematically abused by the rulers, side-stepped, ignored, or even tailored to fit their interests. Political corruption is a deviation from the rational-legal values and principles of the modern state, and the basic problem is the weak accountability between governors and the governed. In authoritarian countries, the legal bases, against which corrupt practices are usually evaluated and judged, are weak and furthermore subject to downright encroachment by the rulers. Political corruption should furthermore be considered as one of the basic modes of operation of authoritarian regimes. It is one of the mechanisms through which the authoritarian power-holders enrich themselves. Here, corruption is rarely a disease that the responsible politicians are eager to avoid, it is a deliberate, wanted and applied practice; it is one of the rulers' modes of enrichment and economic control [1]. Political corruption in all its forms, extent, magnitude and structure is a worldwide phenomenon, however, the myriad of studies and theorizing of corruption $[19,20,2,3]$ shows that colonial and post-colonial Africa is the home to the majority of the most corrupt states in the world. The literature on defining political corruption is enormous using the distinctive ways shared by political scientist in distinguishing it from other forms of political failure and incompetence. Regardless of the political systems, arguments, theorizing, causes and effects of political corruption, the main and decisive actor is the state.

\title{
Political Corruption in Africa: Does Regime Type Play a Role?
}

The past five decades has witnessed myriad of literatures on the study and perception of corruption in Africa that makes explaining corruption in Africa a daunting task to academic inquiry. The pattern of corruption in a nation at a given point in time is in one sense unique. But from a wider perspective, it reflects a configuration of political institutions, popular values, and social strains that many other countries have experienced in greater or lesser degree. Recent speculations about corruption by social scientist are mostly centered in the growing body of literature devoted to the less developed nations. It was clear, especially in the new nations of Africa and Asia, that the façade of politics was deceptive: the political party seemed to operate differently than its western counterpart and economic policy was made according to criteria that were difficult to fathom. In the context of this failure of nominally western institutions to function as anticipated, the search for explanatory factors turned increasingly to traditional social patterns and to more informal political arenas behind the façade [9]. Robert Williams, in his introduction to Political Corruption in Africa, 1987, portrays Western nation's perceptions about corruption in Africa by writing:

\begin{abstract}
A senior British civil servant was visiting a government department in a
West Africa country when he became puzzled by his guide's habit of calling out sums of money as they passed each official's office. Puzzlement turned to outrage when he discovered the amounts represented the going rate for bribing each official. Accustomed to the impeccable standards of the British service, the visitor exclaimed 'Good God! Are there no honest men left in this department?' His guide thought for a moment and replied. 'One or two, but they're very expensive!'
\end{abstract}

Although corruption is neither peculiar to Africa nor peculiarly African, it may be tempting to believe that the above tale is more than apocryphal. Corruption is popularly viewed as the outstanding characteristic of African public life (1) and, if the accuracy of the perceptions is sometimes open to question, the expectations engendered by such attitudes sometimes encourages foreign visitors to expect and detect bribery in almost any encounter with African officials. Corruption in Africa is primarily located in the executive branch of government for the obvious reason that the legislative and judicial branches have generally lost whatever independence and power they may have possessed. It was suggested earlier that it is a mistake to abstract corruption from the political context it occurs. Such an abstraction could imply that explanations of corruption are independent of, or indifferent to, wider disputes about the character of the African state. Disputes about the causes or character of corruption in Africa, in practice, intimately connected to wider debates about development, dependency and the nature of the post-colonial state. Explanations of corruption should therefore be located with an appropriate frame of reference. Various perspectives have been put forth to explain corruption in Africa: Dependency Theory perspective [21]; 'import-export agency' perspective [22]; International capitalism perspective [23, 11]; nationalist perspective [24]; nationalist character of political regimes [25]. Whatever perspective that is used to explain corruption in Africa, it may be functional or dysfunctional, as something to be condoned or condemned. It may be accorded a central explanatory role in interpreting the character of African politics or dismissed as a by-product, a consequence of more important consequence [11]. The study of corruption enables us to penetrate to the actual heart of modern African states, their administrations and their public services, and a phenomenon that is apparently peripheral in nature provides the key to the very center of things. Although the historical data available on corruption during the pre-colonial period are scarce and largely unsystematic, several studies nonetheless establish a clear link between the experience of colonial domination and the institutionalisation of corruption in Africa. In effect, the 'colonial situation' engenders a perception of the public sphere and crystallizes a series of behaviors and power relations which re-create fertile ground for widespread corruption in the modern sense of the term [26]. Since the post-colonial Africa, corruption has been a cause for concern because it diverts already limited funds, undermines economic progress 
and impedes policy changes required for development. Different arguments have been put forward to explain the pervasiveness of corruption in Africa. These include poverty, the personalization of public office and political culture and the inability of leaders to overcome their colonial mentality in respect of their perception of public office [27]. Earnest Harsch, Accumulators and Democrats: Challenging State Corruption in Africa, 1993, in his analysis of the varying perspectives on corruption argues that beyond definitional considerations, there has been a range of analyses of the causes and consequences of corruption in developing countries. In the 1981, The World Bank Berg's report attributed Africa's inferior economic performance in economic growth and poverty reduction to inappropriate state dominated policies that overloaded governments, distorted economic incentives, and generated unproductive monopoly rents [28]. The failure of many structural adjustments programs to transition the continent from a dependency status to a market based economy and propel the continent to growth and development was attributed to among other factors the capture and use of state power. Africa presents a typical case of the countries in the world whose development has been undermined and retarded by the menace of corrupt practices [27] Understanding corruption represents an initial step towards a better understanding of the state, at both central and local levels, a better understanding of administrations, municipalities, development projects and even civil society and the associative movement [26]. Corruption in Africa is a development and social issue which becomes an impediment to change and a serious constraint in economic growth and poverty reduction. Corruption in African countries has become endemic, as such, it is found almost in all aspects of life. Endemic corruption implies a breakdown of the rule of law and in most instances a loss of state legitimacy. It perverts the normal use of connections, networks and reciprocity and leads to increased personalization of power. As a result, people come to rely on connections and favors instead of formal political, social and economic rules and illegitimate use of state resources [27]. Thus, in the words of one of its most widely quoted authors, corruption acts an 'emollient, softening conflict and reducing friction' [29]: it facilitates foreign investments blocked by national protectionism; it makes it possible to circumvent the administrative obstacles that sap entrepreneurial spirit; it promotes national integration and increases citizen participation in public affairs [30, 26]. G. Blundo and J.-P. Olivier de Sardan, Everyday Corruption in West Africa, 2006, in their study of the embeddedness of the levels of corruption in three francophone African states (Niger, Senegal, and Benin) argues that the social phenomena of corruption and their environments can be visualized as a set of concentric circles. The basic forms of corruption- its fundamental mechanisms- are located at the center. These basic forms are integrated into the more complex strategies of the actors who engage in corruption. The basic forms and strategies together constitute the corrupt practices. They, in turn, are set in the routine function of the public services'. The authors in their studies of corruption in these countries identified various forms of corruption, and corrupt strategies. The basic forms of corruption: (Commission paid for illicit services, unwarranted fees for public services, gratuity, string-pulling, the levy or toll, the 'gombo', petty 'white-collar' theft and the 'sideline', and misappropriation); and corrupt strategies includes (corrupt investments, the formation of enduring relationships, the rapid accumulation of wealth, the mutualisation of corruption, the manipulation of corrupt regimes). Needless to say, we were expecting to discover a number of similar behaviors in the different sectors and countries: our own day-to-day encounters with various public services in Africa had accustomed us to certain 'similarities in terms of, for example, the disdain shown to users, the routine pots-de-vin (bribes), the widespread charging of commission, the racketeering by the police and the system of 'favors', which prevailed far beyond the boundaries of individual cultures and regimes [26]. Some scholars like Samuel Huntington, have viewed it as a virtually inevitable phenomenon of the initial phases of modernization, one likely to diminish African economies as they move beyond the earliest stages of capitalist development, as tended to be the case in Western Europe's bourgeois transition. Others emphasize the aspirations of Africa's administrative elites for the status symbols and lifestyles of the continent's former colonial rules, an inclination reinforced at the lower rungs of the bureaucracy by the social disorientation of rapid urbanization. And some point to the pressures of civil servants from primordial public, the networks of traditional kinships and ethnic obligations that require redistribution of acquired wealth and job favors to other members of one's community of origin, a form of solidaristic graft said to draw little moral sanction due to primacy of kinship ties, and the limited legitimacy of the state structures inherited at independence [31]. The colonial phase of African history gave rise to major changes which had far reaching consequences for the nature and extent of corruption. It is, on occasion, temptingly convenient to attribute every undesirable feature of modern African life to the pernicious legacy of colonial rule. It can be blamed for economic underdevelopment, political instability, 'tribalism' and, of course, for corruption. Although African leaders have sometimes found it convenient to use colonialism as a useful scapegoat in deflecting responsibility for their countries' ill, it does not necessarily mean that such charges are without foundation. Regardless of the political systems, arguments, causes and effects of corruption, the main and decisive actor is the state. From colonial times to the present, the centrality of the state has guaranteed that political and economic lives are inescapably intertwined. The pre-eminence and predominance of the state all but precludes the evolution of the pluralistic systems and the absence or weakness of competitive organizations and groupings suggests that a potentially important check and restraint on corruption in Africa [11]. Thus, theft by public officials is probably the most egregious, and in this sense the most 'classic', instance of government corruption. It is important to note that corruption does not always involve an exchange relationship; sometimes the beneficiary is an individual or group who take but give nothing in return [17]. Characterizing public officials in Africa as using the state and its institutions as an arena/instrument to extract and accumulate states' resources for private gains is not the subject for debate, but what needs to be explained about political corruption in Africa is 'Are African democratic regimes less 
corrupt than the authoritarian regimes they succeeded'? Political corruption is consequently a 'normal' condition in authoritarian countries, although sharing a great variety according to the various forms of authoritarianism. However, as demonstrated by many corruption scandals in liberal democracies over the years, political corruption is not restricted to authoritarian systems. Nevertheless, by maintaining the link between authoritarianism and political corruption, and a definition of political corruption in terms of state prerogatives manipulated to serve the interests of the rulers, one will see that the essence of the problem of political corruption differs much between authoritarian and liberal democratic regimes. In democratic countries, the problem of political corruption is more of an incidental and occasional nature, and can be dealt with within the existing political system; by reforming, strengthening and vitalising the existing political institutions of check and balances [1]. However, the failure of many African states to address political corruption as a systematic, endemic social canker and a development issue even though most of these countries have transitioned from authoritarianism to fragile and nascent democracies, raises the question of whether the level of political corruption in Africa is a problem of political regime or the nature and character of the African state? To address this all-important question and address the patterns of political corruption in Africa, it seems more prudent to recognize the possibility that, given the diversity of political regimes and economic circumstances, corruption of the same type may have different causes or consequences in different contexts. It is also necessary to consider whether, or to what extent, corruption is the outcome of unique circumstances, or derives from the predatory ambitions of individual rulers, rather than from general causes, constraints or pressures [11]. In Africa, in less than three decades of independence, corruption has given birth to colossal fortunes, to multi-millionaires, while plunging into misery nearly half a billion human beings. By diverting public funds to their profit, many African leaders must be held responsible, at least in part, for the enormous misery and persistent unemployment in which nearly all the continent's inhabitants are mired [32, 31]. To examine the levels of political corruption in Africa in the past six decades is to answer questions about who rules' and the legitimate authority of the regime types in the post-colonial period to effectively manage resources and improve the well-being of the citizens and propel the continent's development. This requires a careful examination of Africa's authoritarian and democratic regimes since the post -colonial era. As Alina Mingiu-Pippidi [14] noted, particularism mirrors the vicious distribution of power, which in turn is affected by the distribution of resources. In authoritarian regimes, in which power is concentrated and access to power is limited to privilege individuals and groups, particularism prevails. In democracies, politicians are held accountable by the people through elections and concentration of power is further prevented by horizontal mechanisms of checks and balances between branches of government. There is a strong correlation between inequality and clientelism, and the correlation is stronger among countries with longer histories of democracy [33]. A comparative analysis of political corruption in Africa's authoritarian and democratic regimes can be analyzed by examining South Korea's development path and control of political corruption. While South Korea today is widely recognized as a rich and robust democracy with relatively good governance, many Western observers considered the country as hopelessly corrupt and poor autocracy in the 1950s. Since its independence a little more than a half century ago, South Korea has been transitioning, if not completed a transition, from particularism of the limited access order to universalism of the open access [34, 35]. How did this happen? Is the development of good governance based on ethical universalism established by a benevolent dictator or achieved by people's struggles? Have governance norms developed gradually over time, or suddenly at some critical junctures? Who and what factors are responsible for the changes? [33]. Answers to the questions posed by Jong-sung You in, Development of Control of Corruption in South Korea, 20015, may be relevant in the case of Africa. Since gaining independence from the colonial masters' African states have witnessed the seizure of power by a military organization with its leaders setting up a form of authoritarian state and a transition into what Samuel Huntington characterize as the 'Third Wave' of democracy. When African nations became independent around 1960, all the tools for the intensive practice of corruption were already in place [36]. The colonial experience contributed first to the emergence of a new idea of authority and the public service: authority no longer derived from the people, but came from above, was often illegitimate and exercised with brutality, and the public service offered significant opportunities for rapidly accessing material wealth and prestige $[37,38,26]$. Leaders of the new nations were frequently dismayed by the host of special pleadings they were asked to satisfy, by the behavior of their rank and file, and by the widening chasm between the policy decisions framed in the capital and what occurred at the village level. Corruption, which previously has been mentioned only with caution, now seemed to acquire the formidable power to bring down regimes, cripple administration, and sabotage economic growth [9]. All political change in Africa raises the topic of the war against corruption- that is; the popular disapproval of illicit gain by the deposed rulers is mobilized and acts as means of legitimation of the new political classes. However, the latter quickly forget their promises and devote themselves to selective campaigns essentially aimed at excluding rival factions from access to the financial resources necessary to engage in democratic politics [31]. Hence, Commissions of inquiry are a common by-product of regime change [26]. Both civilian and military governments require extensive administrative apparatuses and the structural characteristics of these bureaucratic organizations help determine the shape and location of corruption. Most obviously, if corruption flourishes at the point of discretionary decision, then a highly decentralized form of administration is likely to multiply the number of potentially corrupt encounters between officials and citizens. Conversely, where decision-making authority is highly centralized, field officers will be by-passed and favors sought from the more powerful officials in the capital or it regional headquarters. In crude terms, centralization of bureaucracy helps concentrate corruption while decentralization disperses it around the country. If corruption is prevalent and entrenched under either form, it becomes 
very difficult to reform governmental structures and alter the distribution of authority. Conversely, in the noncompetitive bureaucracy, officials are given monopoly over a clientele. The consequence is that those who rely on specific bureaucratic services are completely dependent on the probity of the official assigned to their case or application. Weber's classic amount of bureaucracy asserts that a careful division of bureaucratic responsibility is more efficient and avoids wasteful duplication but, in Africa it has the effect of strengthening the position of the corrupt officials. The lesson seems to be that order, neatness and precision in the organization of bureaucracy and the allocation of authority may facilitate rather than frustrate corrupt transactions. The exercise of bureaucratic discretion is a manifestation of monopoly over power and this encourages and simplifies the organization of corruption [11]. The patterns of bureaucratic self-serving that emerge can be classified under three headings. First, personalism and patron-client administration create patterns of favoritism, nepotism, and private gain that reflect the fact that obligations of personal loyalty supersede commitments to law or to institutions. Second, because administration is politics, all questions of entry and promotion and virtually all routine decisions are settled by the balance of clique forces and factional interests rather than by regulations or appeals to the public interest. Finally, the absence of any institutionalized bond between the bureaucracy and the public encourages the untrammeled exploitation of office for profit, which often involves the regular extortion of the public the bureaucracy presumably serves. Who are the main beneficiaries of this pattern of corruption? Although detailed evidence is lacking, the principal beneficiaries are likely to be: (1) civilian bureaucrats and/or military officers, (2) individual and groups with parochial (kinship, friendship, and ethnicity) ties to the military or civilian officials, and wealth elites. The military and civilian officials benefit is patently; they control the administrative and coercive force that represents the basis of the regime [9]. The colonial experience which contributed to the emergence of a new idea of public service and authority (authoritarianism and its attendant elements of single party states, clientelism, personalization of political relations and most importantly neopatrimonialism), exacerbated the levels of political corruption in Africa.

\section{Political Regimes and Political Corruption in Africa}

Inge Amundsen, Political Corruption: An Introduction to the Issues, 1999, presents a brief review of this new idea of public service and authority and its relationship with political corruption arguing that authoritarian regimes have ever since usually been understood and portrayed in terms of some ruling elite or class that uses and misuses the powers of the state primarily to safeguard their own corporate interests, at the detriment of -and usually in conflict with -other groups and interests in society. In political terms, the means available for authoritarian rulers range from charisma and persuasion to the overt use of violence. They may use sophisticated institutional arrangements like for instance presidential systems, single party systems, and the cooptation of rivals in order to restrict participation and power sharing. They may use censorship and electoral fraud, establish unjust laws and disrespect the laws they have made themselves, and use human rights violations like political surveillance and intimidation, imprisonment and torture. In economic terms, corruption, and political corruption, is only one of the many modes of economic accumulation and private appropriation applied by authoritarian rulers. Spokesmen for the many new military regimes that have replaced civilian power-holders in Africa and Asia since the late 1950s never failed to cite corruption as a central reason for their seizure of power. Corruption was held responsible for the popular cynicism about politics, for stagnation or decline in per capita income, and for the reduction of national revenue. And the responsibility for growing corruption was laid at the doorstep of the parliamentary system itself. The problem, as the generals saw it, was one of leadership; parliamentary democracy produced weak leaders serving at best a sectional interest and at worst a small coterie of mercenary followers. Such leaders could hardly command discipline or view policy matters from the national interest. While the leaders of military coups often cite widespread corruption as a justification for their intervention in the political process, there seems to be little evidence to suggest that military governments enjoy any more resistance to corruption than their civilian predecessors. It appears that, in most cases, the African military are concerned first and foremost to satisfy their corporate needs and this is reflected in high military spending and other measures intended to raise the status of the army and its leaders. In the last resort, military regimes tend to resist reforms which either encourage political participation or impose restraints on the autonomy of the army. Having removed the civilian political element by coup d'état, the military regime often proves to be merely a variant of bureaucratic government and, as such, is susceptible to the weakness which have affiliated civilian governments in Africa [11]. If state corruption can be viewed as one of the central means of private accumulation in Africa (with some attendant benefits to foreign capital), it must also, however, be recognized as a second-best solution from the perspective of the indigenous bourgeois class formation. Their very dependence on direct state access leaves would-be accumulators vulnerable not only to fluctuations in government revenue, but also to the most passing political wind. The loss of presidential favor or downfall of a political patron can mean an abrupt end to one's business prospects. The accumulation process thus has not been smooth or cumulative, but often fragmentary and episodic. Without a firm, autonomous base of its own, without the security and social power that derive from property and the ownership of means of production, the aspirant bourgeoisie struggling to emerge out of the public sector has remained weak, hesitant, reluctant to take risks, unsure of its own long-term interests. Its insecurity has led it to rely on direct control of the state apparatus to keep in check any political and class challenges from below, over time stripping the government of any semblance of serving the public interests, exposing it instead as a crude instrument of class domination and advancement. With this turbulent entry of masses of people into political activity in recent years, the 
crisis of state legitimacy in much of Africa has become even more evident, forcing not only local authorities to adapt their language and practice, but their foreign patrons to do likewise. Governments in London, Paris, and Washington, previously reticent about criticizing the repressive and corrupt practices of their allies, now found it expedient to proclaim more forcefully support for democracy and human rights in Africa, and to threaten withholding aid from some of the more blatant violators [31]. Are stronger political and institutional restraints on discretionary executive authority the key to eradicating neopatrimonial governance [16], and political corruption? Some democracy-supporters argue that the electorate's capacity to remove 'bad' leaders helps check corruption and cronyism [39-41] as does the transparency that comes with democratic freedoms and the free institutions such as free press and civil society. Lipset [42] argues that wealth and democracy reinforce each other because the middle class of producers, historically speaking, is a stakeholder in a system of political and economic freedom and choice that permits the creation of wealth [43]. The idea that political leaders should be accountable to the citizens through votes acts as a check on corrupt political leaders. This accountability through votes is usually referred to as vertical accountability, to differentiate it from horizontal accountability, whether some state entities, such as the supreme audit institutions, regulators or the judiciary, control and sanction other government entities (check and balances) [44]. The more pessimistic view of the relationship between democracy and corruption argues the following points. First, rapidly expanding political participation by poor electorates leads to expanding demands on governments and excessive government expenditure, leaving fewer resources in the hands of productive investors and reducing growth potential [24]. Second, that democracies, over time, accumulate 'distributional interests' of special interest groups that garner particularistic privileges for themselves from the government and reduce the efficiency and growth potential [40]. Third, Przeworski and Limongi [41] argue that democracy could, in poor country, threaten property rights, create economic uncertainty, and reduce growth. However, all scholars agree that democracy has only an indirect effect on growth, through various mechanisms and institutions [43]. On the relationship between democracy and corruption Rock [45] argues that the relationship between democracy and corruption, by which he means the democratization of erstwhile non-democracies, is like an inverted ' $U$ '. Corruption tends to rise after democratization and then decline after peaking as democracy matures. Rock's argument resembles that of Shleifer and Vishny [46] in that he argues that centralized corruption under authoritarian rule yields to wilder and less efficient corruption under democracy, referring particularly to the cases of Indonesia and Thailand. Since the collapse of the Stalinist regimes in Eastern Europe and the former Soviet Union, the Western powers and the international financial institutions under their control have intensified their promotional campaign in favor of 'democracy'. African governments eager to attract financial assistance therefore faced tangible pressures to move towards more open and competitive political regimes [25, 47]. Meanwhile, rising internal opposition mobilized behind the banner of 'civil society' in seeking to dislodge authoritarian governments $[48,49,50]$. The resulting wave of democratization reinforced broader approaches to governance, moving from narrow focus on public-service reform to include the more ambitious goals of fostering political responsiveness and accountability [51-53, 16]. Since 1988, the people of Africa have risen to replace one-party and military dictatorships with multiparty democracy. From its violent outbreak in October 1988 in the streets of Algiers, this new social movement for democracy has manifested itself all over the continent, changing the rules of the political game and bringing about meaningful reforms in the institutions of the postcolonial state [54]. The crises of the African authoritarian political systems were to make way for a transition to democracy in Africa which will in part help promote and build participatory and representative institutions that will allow for a measure of citizenry bargaining and constructive engagement in government policy formulation towards development. The heavily centralized statism that marked the first decades of independence has been subjected to scrutiny in recent years. And although many of the authoritarian and repressive tendencies of the first independence generation persisted throughout the 1990s, most countries undertook reviews of the structure of the public sphere and others proceeded to make institutional adjustments as well [49]. During the onset of multiparty democracy in the so called third wave of democratization, most regimes in the African Nations did not embrace the changes that accompanied the transition. For instance, most nations accepted multiparty democracy out of western pressure and agitation for change [55]. As a result, the constitutional framework and the state institutions have been tempered with to create a non-level playing ground for the oppositions [56]. As the primary stage of the struggle between the forces of the status quo and those of change, the internal environment is absolutely crucial as to its effects on the democratization process. Within the democracy movement itself, there is a glaring contradiction between the deepest aspirations of the masses, who constitute the rank and file, and the narrow class interests of its leadership. The latter is made up in most cases of deserters from the ruling class circles of the ancient regime, who are more interested in settling accounts with their former boss and his entourage than in transforming the state radically by democratizing it and increasing its capacity to serve the people. Like most of the petty bourgeoisie leaders of the independence struggle, the new leaders are for the most part self-centered seekers of political power and material benefits. Their main preoccupation is to position themselves for political office in the new dispensation of the post-authoritarian era. Evidence from both the aborted or failed transitions, and the countries where elected governments have replaced civilian military dictatorships, suggests that there is little commitment to democratization as a process within the political class, including leaders of the democratic opposition $[35,54]$. Both powerholders and those seeking to replace them share a common political culture, one "that puts less emphasis on respect for the democratic process of open debate and transparent decision-making than on deal-making among politicians" [49]. Whereas the earlier generation of African leaders had viewed democracy and development as antithetical, associated democracy with ethnic 
conflicts resulting in wastage of limited resources, new African elites and organizations in civil society have taken to the barricades to demand democracy not only for its own sake but for its instrumental value as well. In contrast to the intellectual consensus and state practice of the earlier era, a strong linkage between democracy and development has been vigorously asserted in the post- Cold War era of superpower disinterest and withdrawal [57, 46, 36, 48, 58, 59, 56]. The democratic principles of human rights, civil liberties, freedom of religion, press, assembly, association, social and economic justice etc., were relegated to the background in pursuit of free-market economic principles to benefits western patrons. The need to subjugate Africa to the logic of global capitalist expansion is contrary to the requirements of democracy. It favors instead rule by a technocratic elite that can only be anti-labor, anti-people, and therefore antidemocracy. Thus, despite their declarations of good intentions, the major forces in the world system prefer technocrats without a political base in a country to leaders who have a national constituency. While the latter are likely to listen to their consciousness, the former can be expected to be beholden to their foreign patrons. They will, accordingly implement externally mandated policies to benefit their patrons to the detriment of their people [54]. Ake goes on to argue that subjugation has caused Africa's human resources, the very engine of development, to be squandered [57, 56]. The new institutional limit on government authority which democracy was envisioned to provide to restrain authoritarianism and fiscal austerity on economic development was undermined by weak institutions. With weak institutional checks on the private appropriation of public resources, patronage networks permeate the state's administrative structures, compromising public-service effectiveness and fueling corruption. However, the new institutional economics suggests that governance quality can be conceivably being quite sensitive to prevailing political institutions. For example, institutions improving the alignment between African government' political incentives and development objectives would be expected to produce more constructive policies and systems of public administration. They would, in this sense, provide political foundations for the organizational cohesion and social embeddedness of what are sometimes called 'development' state [60-62, 16]. Given this fact, the challenges of social, economic and political development for sub-Saharan Africa have remained in the front burner of development discourse in the world for the last three (3) decades or more. This is borne out of the grim reality of statistical data which revealed that of the about 80 percent of the world's population which lives in the developing world, the people's lifestyles are marked by low incomes, high poverty, unemployment and low education [27]. Despite the major obstacles: political immaturity of the democratic forces, the weakness of the means of subsistence of the middle class and its exploitation by the ruling group, monopoly of the public media by the incumbent regime, violence as against democracy to the democratic transition that Gorges Nzongola-Ntalaja and Margaret C. Lee present in their introduction to 'Democracy and the Democratic Transition in Africa', in the 'The State and Democracy in Africa'. The authors argue that today, no state can succeed in wiping out the major gains of the democracy movement like freedom of expression, press, and assembly, as well as the penetration of the political space by NGOs. The people no longer fear Africa's dictators and their repressive machines, as they are determined to go forward until final victory. Achieving this victory and sustaining the democratic gains made are a function of the environment within which the democratization process takes place. Important variables of an enabling environment include the development of a viable society, electoral politics and their outcomes, political arrangements made with respect to a democratic governance, peace and security, and economic conditions [54]. Research analysis on case studies on Ghana, Nigeria, and the D.R. Congo, which examines military regimes transitioning to democratic dispensation, reveal that though democratic transition has taken hold in Africa, with military elites, no longer receiving the privileges they had held during easier times will turn on elected leaders and remove them from office. Just as it is likely to be sustained under conditions of peace and security, the democratic transition offers the best conditions for normal reconciliation and social justice, which are the foundations of durable peace and comprehensive security [54]. Most of Africa's authoritarian military and civilian regimes acceptance of multiparty democracy out of western pressure and agitation for social change to bring about the necessary economic development have been undermined by the pursuit of free-market economic principles. It is this push for social change that has brought to fore the demand for sustainable, equitable and democratic development; where the economic and political institutions work for the benefits of the greatest majority as well as create a social environment where the people have a greater say in the decision-making processes that ultimately affect their existence. This is significantly so as the major factor that determines how well a country will do is a function of the 'quality' of the public and private institutions, from which decisions get made and in whose interest. However, the development agenda in many African countries have been undermined by several factors, including inept leadership, weak states, institutional impunity, massive corruption which have stifled their quest for socioeconomic transformation. From this context, therefore, one begins to examine the role of the state which is the institution that deals with the organization of power, from which various sets of political relationships takes place with respect to the exercise of power, especially political power. In other words, the state is the contemporary locus of power and authority, and the most inclusive unit within which control is exercised. It is this character of the state that was carried to independence and has continued till such date that the quest for state power has only increased the political intensity for competition and conflict among our political leaders but also created the tendency to use the state for private accumulation [63]. The new institutional limits on government authority which western powers envisioned the new wave of democracy by restraining authoritarianism through promoting and building participatory representative institutions that will allow for a measure of citizenry bargaining and constructive engagement in policy formulations towards development raises new concerns about the different degrees of democracy and corruption. This idea of different 'degrees of democracy' is of profound relevance 
for the link between democracy and corruption. It suggests that the alleged positive impact of democracy on corruption control is not so much due to the compliance with the existence, de jure, of some democratic institutions on paper, but hinges upon the effective implementation and working of these democratic institutions. Such an effective implementation may take time, is likely to be highly incremental, and may suffer from reversals as well. Indeed, the historic evidence of democratic institutions seems even to suggest that effective democratic institutions are often a by-product of political struggle and contention of elites over power [52, 10, 64]. However, at the same time recent evidence from countries that switched to or returned to democracy seems to show that this is not the whole story. As Sung [33] notes: political liberalization has made matters worse in most of those countries that embarked on the democratic transition in the 1980s and 1990s. Indeed, electoral competition in some countries seems rather to have incremented corrupt practices such as vote-buying to gain elections. The public office is often abused to extract as much public money, e.g. through corrupt practices in public procurement, as possible and perhaps to secure political support for re-election, e.g. using clientelist practices. Nonetheless, the main conclusion that may be drawn from historical analyses of African politics is that, even if the visibility and forms taken by corruption tend to depend on the specific nature of different types of political regimes, no single type, be it authoritarian or pluralist, military or civil, is more likely than the other to engender corruption. Thus, it is plausible to follow Medard's lead and establish a correlation between the stability of a regime and the forms of corruption that occur under it. In other words, the political elites are past masters that fulfils the expectations and conditions of their donors and is extremely far removed from the realities that remain largely inaccessible to the donorsthat is, the very people who wish to inspire or impose the 'war against corruption' as a condition for the granting of their support. On the other hand, the discourse surrounding the war against corruption among the power elites also constitute a response to internal political issues (i.e. elimination of political competitors, the elimination of groups that were defeated in the polls, the creation of scapegoats to satisfy public expectations etc.) involving the settling of old scores and not the real improvement of governance [26]. Because of the pervasiveness of political corruption in Africa and the failures of the principal-agency and institutional models to address corruption, alternative explanatory based on state-society relationship and who benefits most from political corruption in Africa should be encouraged. This will mean examining the roles of foreign financial institutions and theorizing on a transfer-abetment mechanism of siphoned resources in the form of illicit financial flows (IFCs) to Western nations. To this end, the extractive theory of political corruption and the theory of the corrupt African state provides alternative explanations to corrupt practices in Africa, by examining corruption from the political context with emphasis and analysis on the state, as the stronger party in state-society relationship and the character and policies of African governments using state institutions as arenas to extract and allocate public resources (property and jobs) to both domestic and foreign solidarities.

\section{REFERENCES}

1. Amundsen, I. (1997). Political Corruption: An Introduction to the Issues, Working Paper 1997: 7, Development Studies and Human Rights.

2. Rose-Ackerman, S. (1978). Corruption: A Study in Political Economy. New York: Academic Press.

3. Klitgaard, R.E. (1988). Controlling Corruption. Berkeley: University of California Press.

4. Myerson, R.B. (1993). Effectiveness of Electoral Systems for Reducing Government Corruption: A Game-Theoretic Analysis. Games and Economic Behavior, 5(1): 118-132.

5. Persson, T., \& Guido, T. (2000). Political Economics: Explaining Economic Policy. Cambridge: The MIT Press.

6. Besley, T. (2006). Principled Agents? The Political Economy of Good Governance. Oxford: Oxford University Press.

7. Teorell, J. (2007). Corruption as an Institution: Rethinking the Nature and Origins of the Grabbing Hand. Working Paper, 2007:5. Gothenburg: The Quality of Government Institute, University of Gothenburg.

8. The World Bank. (1997). World Development 1997: The State in a Changing World.

9. Scott, J. (1972). Comparative Political Corruption. Englewood Cliffs, NJ. Prentice Hall.

10. Johnston, M. (2002). "Right or Wrong in American Politics: Popular Conceptions of Corruption", in: Arnold J. Heidenheimer and Michael Johnston, eds. Political Corruption: Concepts and Contexts, Third Edition. Transaction Publishers.

11. Williams, R. (1987). Political Corruption in Africa. Dartmouth Publishing Co. Ltd.

12. (1989). L'Etat en Afrique. La Politique du ventre, Fauard, Paris.

13. Ndikumana, L. (2006). Corruption and Pro-Poor Growth Outcomes: Evidence and Lessons for African Countries. Political Economy Research Institute, Amherst: University of Massachusetts WP, No. 120.

14. Mungiu-Pippidi, A. (2006). Corruption: Diagnosis and Treatment. Journal of Democracy, 34(2): 349-359.

15. Medard, J-P. (2002). Corruption in the Neo-Patrimonial States of Sub-Saharan Africa. In: Political CorruptionConcepts and Contexts, edited by Arnold J. Heindenheimer, and Michael Johnston, 379-402. New Brunswick \& London: Transaction Publishers.

16. Alence, R. (2004). Political Institutions and Developmental Governance in Sub-Sharan Africa, Journal of Modern Africa Studies, 42, 2.

17. Gerring, J., \& Strom, C. Thacker. (2004). Political Institutions and Corruption: The Role of Unitarism and Parliamentarism. Cambridge University Press. 
18. Philip, M. (2000). “Conceptualizing Political Corruption”, in: Arnold J. Heidenheimer and Michael Johnston eds. Political Corruption: Concepts and Contexts. Transaction Publishers.

19. Bhagwati, J.N., ed. (1974). Illegal Transactions in International Trade. Amsterdam and New York: North-HollandAmerican Elsevier.

20. Krueger, A.O. (1974). "The Political Economy of the Rent-Seeking Society". American Economic Review 63 (June), 291-303.

21. Higgot, R. (1983). Political Development Theory: The Contemporary Debate, Croom Helm.

22. Dunn, J. ed. (1978). West African States: Failure and Promise: A Study in Comparative Politics, Cambridge University Press

23. Crook, R.C. (1983). Democracy and Decentralization in South Asia and West Africa, in: Lyon, P., and J. Manor, eds. Transfer and Transformation: Political Institutions in the New Commonwealth. Leicester University Press.

24. Huntington, S.P., \& J.M. Nelson. (1976). No Easy Choice: Political Participation in Developing Countries. Cambridge: Harvard University Press.

25. Clapham, C. (1996). 'Africa's External Economic Relations, 1960-90', African Affairs 90, 360: 339-56.

26. Blundo, G., \& J-P Olivier de Sardan. (2006). Why Should We Study Everyday Corruption and How Should We Go About it, In: G. Blundo, and J-P. Olivier de Sardan with N.N. Arifari and M.T. Alou, Everyday Corruption and the State: Citizens and Public Officials in Africa. London and New York: Zed Books.

27. Lawal, G. (2007). Corruption and Development in Africa: Challenges for Political and Economic Change, Human and Social Science Journal, 2(1).

28. The World Bank. (1981). Accelerated Development in Sub-Saharan Africa: An Agenda for Action.

29. McMullan, M. (1961). A Theory of Corruption Based on a Consideration of Corruption in the Public Services and Governments of British Colonies and ex-Colonies in West Africa, The Sociological Review, 9(2), 181-201.

30. Gould, R. A. (1980). Living archaeology. CUP Archive.

31. Harsch, E. (1993). Accumulators and Democrats: Challenging State Corruption, 31(1), March., 1993), 31-48.

32. Sarassoro, H.C. (1990). 'La Corruption et l'enrichissement sans cause en Afrique aujourd'hui, in Afrique contemporaine (Paris), 156, 4th quarté, 1990, 195.

33. You, Jong-sung. (2015). Development of Control of Corruption in South Korea, German Institute of Global and Area Studies. Australian National University.

34. North, D. C., John, W., \& Barry, R. Weingast. (2009). Violence and Social Orders: A Conceptual Framework for Interpreting Recorded Human History. Cambridge: Cambridge University Press.

35. Young, C. (1982). Ideology and Development in Africa. New Haven: Yale University Press.

36. Bayart, J.-F. (1993). The State in Africa: The Politics of the Belly, Longman, New York.

37. Njoku. U. J. (2005). 'Colonial Political Re-Engineering and the Genesis of Modern Corruption in African Public Service: The Issue of the Warrant Chiefs of South Eastern Nigeria as a Case in Point', Nordic Journal of African Studies, 14(1), 99-116.

38. Tignor. R.L. (1971). 'Colonial Chiefs in Chiefless Societies', Journal of Modern African Studies, 9(3), 339-59.

39. North, D.C. (1990). Institutions, Institutional Change and Economic Performance. New York: Cambridge University Press.

40. Olson, M. (1993). "Dictatorship, Democracy, and Development”, American Political Science Review, 87(30):567576.

41. Przeworski, A., \& F. Limongi. (1993). "Political Regimes and Economic Growth". Journal of Economic Perspectives 7.

42. Lipset, S.M. (1959). "Some Social Requisites of Democracy". American Political Science Review 53.

43. Sridharan, E. (2014). India: Democracy and Corruption, Paper Presented on April 20, 2013 at Democracy Works Project Seminar at Center for Development and Enterprise.

44. Boehm, F. (2015). Democracy and Corruption. Dimension Empresarial, 13(2),75-85

45. Rock, M.T. (2009). "Corruption and Democracy”. Journal of Development Studies, 45(1)

46. Shleifer, A., \& Robert W. Vishny. 1993. Corruption, The Quarterly Journal of Economics, 108, 3; 599-617

47. Haberson, J.W. (2000). 'Externally Assisted Democratization: Theoretical Issues and African Realities', in: J.W. Haberson \& D. Tothchild, eds. Africa in World Politics: the African State in flux, 3rd edn. Boulder, CO:Westview, 235-59.

48. Anyang' Nyong'o, P. ed. (1987). Popular Struggles for Democracy in Africa. London: Zed.

49. Haberson, J.W., D. Rothchild., \& N. Chazan, eds. (1994). Civil Society and the State in Africa. Boulder, CO: Lynne Rienner.

50. Lewis, P.M. (1992). 'Political Transition and the Dilemma of Civil Society in Africa. Journal of International Affairs, 46, 1: 31-54

51. Diamond, L. (2001). 'Developing Democracy in Africa: African and International Perspectives', paper presented at Stanford University Workshop on 'Democracy in Africa in Comparative Perspectives'.

52. Healey, J., \& M. Robinson. (1992). Democracy, Governance and Economic Policy: sub-Saharan Africa in Comparative Perspective. London: Overseas Development Institute. 
53. Hyden, G. (1992). 'Governance and the Study of Politics', in: G. Hyden \& M. Bratton, eds. Governance and Politics in Africa. Boulder, CO: Lynne Rienner.

54. Nzongola-Ntalaja, G., \& Lee, M. C. (Eds.). (1998). The state and democracy in Africa. Africa World Press.

55. Huntington, S. (1991). Democracy's Third Wave, Journal of Democracy, 2(2).

56. Ibrahim, A. A., \& Cheri, L. (2013). Democracy, political instability and the African crisis of underdevelopment. Journal of Power, Politics \& Governance, 1(1), 59-67.

57. (1990). 'La Corruption en Afrique', Histoires de development 9: 36-40

58. Callaghy, T.M. (1987). 'The State as Lame Leviathan: The Patrimonial Administrative State in Africa', In: Z. Ergas, ed. The African State in Transition. Basingstoke: Macmillan, 87-116.

59. Holmquist, G. P. (1989). Evolution of chromosome bands: molecular ecology of noncoding DNA. Journal of molecular evolution, 28(6), 469-486.

60. Englebert, P. (2002). State Legitimacy and Development in Africa. Lynne Rienner Publishers.

61. Mangelsdorf, D. J., \& Evans, R. M. (1995). The RXR heterodimers and orphan receptors. Cell, 83(6), 841-850.

62. Mkandawire, T. (2001). Thinking about developmental states in Africa. Cambridge journal of economics, 25(3), 289-314.

63. Egharevba, E.M., \& Chiazor, A. Idohu. (2012). Political Corruption and National Development in Nigeria, Paper Presented at the International Conference on Democracy, Governance and Curbing Corruption in sub-Saharan Africa, Cheyney University of Pennsylvania, USA August, 8-10, 2012.

64. North, D. C., Wallis, J. J., Webb, S. B., \& Weingast, B. R. (2012). Limited access orders (pp. 1-23). New York: Cambridge University Press. 